\title{
The Directors' Duty to Exercise Care and Skill in Contemporary South African Company Law and the Business Judgment Rule
}

\author{
Jean Chrysostome Kanamugire \\ Lecturer, Faculty of Law, Mafikeng Campus, North-West University \\ Email: jean.kanamugire@nwu.ac.za/Email: kajec1@yahoo.co.uk
}

Terence Vincent Chimuka

Legal Adviser, KwaZulu-Natal Department of Economic Development and Tourism, South Africa

Email: chimukat@kznded.gov.za

\section{Doi:10.5901/mjss.2014.v5n20p70}

\section{Abstract}

Directors have a duty to exercise care and skill in the performance of their activities. They must carry out the functions of their office and exercise the powers bona fide for the benefit of the company. Long ago, courts restrained themselves from assessing the performance of directors in running the company. However, directors are under constant scrutiny. They can be held delictually liable if they failed to properly exercise their duty of care and skill. Courts use the objective and subjective approaches to determine the liability of directors. The Companies Act 71 of 2008 has partially codified the common law directors' duty of care, skill and diligence. The directors have to display or demonstrate care and skill of the person holding the same position. However, the directors' knowledge and skill are also considered in determining what they can perform for the company. The Companies Act has introduced the business judgment rule as a defence for directors to avoid liability.

Keywords: Directors, duty of care and skill, delictual liability, business judgment rule

\section{Introduction}

Companies appoint directors to carry out day-to-day functions required by the company. ${ }^{1} \mathrm{~A}$ company director, apart from owing the company a fiduciary duty, is also under a duty to exercise care and skill when executing his or her duties. ${ }^{2} \mathrm{~A}$ director's duty of care and skill entails that he or she must carry out the functions of his or her office ${ }^{3}$ and exercise the powers of that office bona fide for the benefit of the company. ${ }^{4}$ In South Africa, the common law duty of directors to exercise care and skill has been partially codified by the Companies Act. ${ }^{5}$ There are practical difficulties in prescribing an appropriate and acceptable standard of care and skill for company directors mainly because directors are not members of a professional body. ${ }^{6}$ At common law the courts exercised judicial restraint when they assessed the directors' exercise of powers in running the company. ${ }^{7}$ However with changes in the corporate landscape across the world, directors' decisions are under constant scrutiny. ${ }^{8} \mathrm{~A}$ director who fails to observe his or her duties of care and skill to the company can be held liable in delict for damages. ${ }^{9}$ In order to counter the new less subjective and more rigorous duty of directors to exercise care, skill and diligence, the Companies Act 71 of 2008 imported the Business Judgment Rule as a defence to be used by directors. ${ }^{10}$ This article examines a director's duty to exercise care and skill under the common law. It also discusses

\footnotetext{
${ }^{1}$ Hulse-Reutter v Godde 2001 (4) SA 1336 (SCA) 1346A-B; see also, Visser, Pretorius, Sharrock and Van Jaarsveld Gibson.South African Mercantile and Company Law. 8ed. (2003) 259-262.

2 Cilliers, Benade, Henning, Du Plessis, Delport, De Koker and Pretorius.Corporate Law. 3rd ed. (2000) 147; RC, Williams. Concise Corporate and Partnership Law.2nd ed. (1997) 161 , the duty to exercise care and skill is not a fiduciary duty.

${ }^{3}$ According to Rogers CJ in Daniels (formerly practicing as Deloitte Haskins \& Sells) v Anderson (1995) 37 NSWLR 438 articulated that skill refers to the technical competence of a director, while care is the manner in which the skill is applied.

4 D Lee "The Business Judgment Rule: Should it Protect Nonprofit Directors?" (2003) 103 Columbia Law Review 945.

${ }^{5}$ Companies Act 71 of 2008, s 76(3). The common law duty of a director to exercise care and skill remains relevant.

${ }^{6} \mathrm{FHI}$, Cassim. et al. Contemporary Company Law.2ed. (2012) 555.

7 V Finch. 'Company Directors: Who Cares about Skill and Care'? (1992) 55 Modern LR 179 at 179 stated that "the common law operates to give directors a remarkable freedom to run companies incompetently. Provided that their behavior falls short of the grossest negligence they are unlikely to be held to account."

${ }^{8} \mathrm{FHI}$ Cassim. et al. Contemporary Company Law 2ed (2012) 558, articulates that nowadays a company director of a listed company is a highly skilled professional with considerable business experience and section 76(3) (c) reflects that.

${ }^{9}$ Du Plessis NO v Phelps 1995 (4) SA 165 (C) 170B-C

10 Companies Act 71 of 2008; s 76(4). This section is often referred to as the safe- harbour provision for directors.
} 
the partially codified directors' duty to exercise care, skill and diligence under the Companies Act of 2008 and its relationship with the Business Judgment Rule.

\section{The Common Law Duty of Directors to Exercise Care and Skill}

If a director did not exercise care and skill in executing his or her duties then s/he will be liable for any loss suffered by the company as a result of his or her conduct. The director's liability stems from delict and in some instances from a breach of contract. In Du Plessis NO v Phelps, ${ }^{11}$ Friedman JP ruled that "Apart from their statutory duties, directors owe fiduciary duties to the company as well as a common law duty to take reasonable care in the management of the company's affairs. Liability in the event of a director failing to take reasonable care in the management of the company's affairs is based on the principles of the Lex Aquilia. The basic requisite for liability under the Lex Aquilia is fault, i.e. dolus or culpa which results in loss to the plaintiff." 12

South African law regarding directors' duty of care and skill has been influenced heavily by English law. ${ }^{13}$ Consequently, English law and South African law adopted a conservative attitude towards the directors' duty of care and skill. ${ }^{14}$ Historically the common law made little demands on directors to exercise care and skill, and the directors were at liberty to manage the companies albeit incompetently. ${ }^{15}$ The duty was couched in undemanding terms. ${ }^{16}$ At common law a director was required, in the performance of his or her duties, to exercise the care and skill that may be expected of a person with his or her knowledge and experience. ${ }^{17} \mathrm{~A}$ mere error in judgment in the absence of gross negligence was not enough to find a director liable. ${ }^{18}$

The leading case in South Africa is Fisheries Development Corporation of SA Ltd v Jorgensen \& Another; Fisheries Development Corporation of SA Ltd v AWJ Investments (Pty) Ltd \& Others. ${ }^{19}$ Margo J articulated the principles reflecting the legal position in South Africa. Firstly, the extent of a director's duty of care and skill depends to a considerable degree on the nature of the company's business and on any other particular obligation assumed by or assigned to the specific director. ${ }^{20}$ Differentiation is also made between the so-called full-time or executive director who participates in the day to day management of the affairs of the company, and the non-executive director whose duties are of an intermittent nature. ${ }^{21}$ The non-executive director is not bound to give continuous attention to the affairs of the company but has to perform his or her duties at periodical board meetings or any other meeting that may require his or her attention. ${ }^{22} \mathrm{~S} / \mathrm{he}$ is not bound to attend all such meetings although s/he ought to whenever s/he is reasonably able to do so.

Secondly, a director is not required to have any special business acumen or expertise, ability or intelligence, or even expertise in the business of the company. ${ }^{23}$ However he or she is expected to exercise the care which can reasonably be expected of a person of his or her knowledge and experience. A mere error of judgment will not lead to the director being liable. ${ }^{24}$ There is a further striking contrast between director's heavy duties of loyalty and good faith and his or her less onerous obligations of skill and diligence. Nevertheless, a director may not be indifferent or a mere dummy. ${ }^{25}$ Nor may he or she shelter behind culpable ignorance or failure to understand the company's affairs.

Thirdly, in respect of all duties that may be left to some officials, a director is, in the absence of suspicion, justified in trusting that officials to perform such duties honestly. ${ }^{26} \mathrm{~A}$ director is also entitled to rely on the judgment, information and advice of the management unless proper reasons exist for querying such. ${ }^{27}$ However, a director exercising

\footnotetext{
${ }^{11}$ Du Plessis NO v Phelps1995 (4) SA 165 (C).

12 Ibid 170B-C

${ }^{13} \mathrm{JJ}, \mathrm{Du}$ Plessis "A comparative analysis of directors' duty of care, skill and diligence in South Africa and in Australia" (2010) ActaJuridica 236.

$14 \mathrm{Ibid}$. a subjective as opposed to an objective test was used to measure the director's negligence or otherwise.

${ }^{15}$ M Bekink "An Historical Overview of the Director's Duty of Care and Skill: From the Nineteenth Century to the Companies Bill of 2007" (2008) 20 Merc LJ 95, 97.

${ }^{16}$ FHI Cassim et al.Contemporary Company Law. 2ed. (2012) 555.

17 Ibid. see also Re Brazilian Rubber Plantations \& Estates Ltd(1911) Ch 425 CA 437, where the court held that a director 's duty is to act with such care as is reasonably expected from him, having regard to his or her knowledge and experience.

${ }^{18}$ Overend\& Gurney Co v Gibb(1872) LR $5 \mathrm{HL} 480$ (HL) 487, the negligence which attracted liability was described as being "cognizant of circumstances of such character, so plain, so manifest, and so simple of appreciation, that no men with an ordinary degree of prudence, acting on their behalf would have acted accordingly."

${ }_{19}^{19}$ Fisheries Development Corporation of SA Ltd v Jorgensen \& Another; Fisheries Development of SA Ltd v AWJ Investments (Pty) Ltd \& Others 1980 (4) SA 156 (W) at 156.

20Ibid 165 G-H; Re City Equitable Fire Insurance Co Ltd1925 Ch 407 at 427.

${ }^{21}$ Fisheries Development Corporation of SA Ltd v Jorgensen (note 19 above) 165H. The King Report on Corporate Governance for South Africa (Institute of Directors in Southern Africa) March 2002 at 54 makes a distinction between the role of executive directors and the role of non-executive directors, although both have to observe the duty of care and skill, the executive directors, because of their intimate knowledge of the company, more is expected from them.

22 See Re Denham \&Co (1884) LR 25 Ch D 752, where a director was not found guilty of negligence despite not having performed their duties for four years. See also In Re City Equitable Fire Insurance Co Ltd 1925 Ch 407.

${ }^{23}$ See Fisheries Development Corporation of SA Ltd v Jorgensen 1980 (4) SA 156 (W) 166 A

${ }_{24}^{4}$ /bid 165B; Lagunas Nitrate Co v Lagunas Nitrate Syndicate (1899) 2 Ch 392 at 435.

${ }^{25}$ Fisheries Development Corporation of SA Ltd v Jorgensen (note 19 above) 166C; Huckerby v Elliot 19701 All ER 189 at 193j-194d the court stated that a director exercising reasonable care would not accept information blindly.

${ }^{26}$ Re City Equitable Fire Insurance Co Ltd supra at 429

${ }^{27}$ Re City Equitable Fire Insurance Co Ltd at 429-30; Huckerby v Elliott (1970) 1 All ER 189 (QB) 193-194.
} 
reasonable care would not accept information and advice blindly but would give it due consideration and exercise his or her own judgment accordingly. Each director must thus make the necessary effort to understand the company business and affairs and exercise his or her own judgment based on personal knowledge and experience as well as the information and advice given by the company officials.

In Re Brazilian Rubber Plantations and Estates Ltd, ${ }^{28}$ Neville $\mathrm{J}$ summarised the attitude of the courts on the directors' duty to exercise care and skill. The learned judge stated that:

So long as they act honestly, they cannot be made responsible in damages unless guilty of gross negligence. There is admittedly a want of precision in this statement of a director's liability. In truth, one cannot say whether a man has been guilty of negligence, gross or otherwise, unless one can determine what is the extent of the duty which he is alleged to have neglected. A director's duty has been laid down as requiring him to act with such care as is reasonable to be expected from him, having regard to his knowledge and experience. He is, I think, not bound to bring any special qualification to his office. He may undertake the management of a rubber company in complete ignorance of everything connected with rubber without incurring responsibility for the mistakes which may result from such ignorance, while if he is acquainted with the rubber business, he must give the company the advantage of his knowledge when transacting the company's business. He is not, I think bound to take any definite part in the conduct of the company's business, but as far as he does undertake it, he must use reasonable care to its dispatch. ${ }^{29}$

It is clear that under the common law ordinary negligence alone was not sufficient to hold directors liable for breach of their duty of care and skill. ${ }^{30}$ In Daniels $v$ Anderson, ${ }^{31}$ the court, after considering leading English cases, ${ }^{32}$ concluded that "the negligence spoken of was something grosser or more culpable determined by subjective tests?"

South African courts have relied on English judicial precedence and followed a lenient approach in holding directors accountable for breach of their duty of care and skill. ${ }^{33}$ In this regard, a subjective test was used to determine or ascertain the duty of care and skill. The reasoning behind this approach was that shareholders were responsible for the competence of appointing directors and those directors were not full time and most directors were employed for their reputation rather than their skill and expertise. ${ }^{34}$

\section{Movement Towards a Stringent Director's Duty of Care and Skill in South Africa}

The test for a director's duty of care and skill has been criticised in recent times as being relatively low. ${ }^{35}$ Du Plessis ${ }^{36}$ is of the view that the scene has changed considerably for directors in recent years since the influential English decision of In Re City Equitable Fire Insurance Co Ltd. A good example is the case of Daniels v Anderson, ${ }^{37}$ although an Australian case, it has had a huge influence in South Africa. The court held that the modern law of negligence should be used to determine whether a director was in breach of his or her fiduciary duty. It also suggested that a more objective approach to the director's duty to exercise care and skill is appropriate. ${ }^{38}$ The case of Daniels $v$ Anderson therefore represents a change of attitude by the courts not only in Australia but also in South Africa as it brings an abrupt end to the notions that a director's duty of care, skill and diligence should be subjectively assessed. ${ }^{39}$

An indication of a movement towards an objective approach into the directors' duty of care and skill is evidenced by section 43 of the South African Close Corporations Act. ${ }^{40}$ Section 43(1) states that: "A member of a corporation shall be liable to the corporation for loss caused by his failure in the carrying on of the business of the corporation to act with the degree of care and skill that may reasonably be expected from a person of his knowledge and experience."

The other piece of legislation worth mentioning is the Banks Act. ${ }^{41}$ This Act regulates all the banks in the Republic of South Africa, and in terms of section 60(1) of the Banks Act of 1990 directors owe the bank a fiduciary duty and a duty

\footnotetext{
${ }^{28}$ Re Brazilian Rubber Plantations and Estates Ltd (1911) 1 Ch 425 (Ch D).

29 lbid 436-7.

30 JJ Du Plessis. "A comparative analysis of directors' duty of care, skill and diligence in South Africa and in Australia" (2010) Acta Juridica 6.

${ }^{31}$ Daniels v Anderson16 ACSR 607 (CA) (NSW) 657.

32Lagunas Nitrate Co v Lagunas Syndicate (1899) 2 Ch 392 (CA); Re National Bank of Wales Ltd (1899) 2 Ch 629 (CA); Sheffied and South Yorkshire Permanent Building Society v Aizlewood (1889) 44 (Ch D) 412

${ }^{33}$ N, Bouwman. "An Appraisal of the Modification of the Director's Duty of Care and Skill" (2009) 21 SA Merc LJ 511

${ }^{34} \mathrm{Ibid}$.

${ }^{35}$ See D Botha and R Jooste "A Critique of the Recommendations in the King Report Regarding a Director's Duty of Care and Skill" (1997) 114 SALJ 76.

36JJ Du Plessis "A comparative analysis of directors' duty of care, skill and diligence in South Africa and in Australia” (2010) Acta Juridica 8.

${ }^{37}$ Daniels v Anderson16 ACSR 607 CA (NSW) at 664-665.

${ }^{38} \mathrm{lbid}$.

$39 \mathrm{lbid}$.

${ }^{40}$ Close Corporations Act 69 of 1984

${ }^{41}$ Banks Act 94 of 1990.
} 
of care and skill. The directors have to act bona fide for the benefit of the bank and avoid any conflict of interest. ${ }^{42}$ Section 60 also states that a director must possess and maintain the knowledge and skill that may reasonably be expected of a person holding a similar appointment or carrying out similar functions; the director is expected to exercise the care in carrying out his or her functions in relation to the bank as may reasonably be expected of a diligent person who holds the same appointment under similar circumstances, and who possesses both the knowledge and skill of the position of a director and any such additional knowledge and skill as the director in question may have..$^{43}$

The King II Report ${ }^{44}$ is also important in this regard as it has provided certain guidelines for directors in performing their duties of care and skill. The report stated that directors:

"Must, in line with modern trends worldwide, not only exhibit the degree of skill and care as may be reasonably expected from persons of their skill and experience, but must also:

Exercise both the care and skill any reasonable person would be expected to show in looking after their own affairs as well as having regard to their actual knowledge and experience; and

Qualify themselves on a continuous basis with sufficient understanding of the company's business and the effects of the economy so as to discharge their duties properly, including where necessary rely on expert advice." 45

It therefore did not come as a surprise that the Companies Act 71 of 2008 followed this trend and codified the directors' duty to exercise care, skill and diligence.

\section{A Director's Duty to Exercise Care, Skill and Diligence under the Companies Act 71 of 2008}

The Companies Act ${ }^{46}$ upgrades the director's duty of care and skill, and it imposes a less subjective and more demanding standard for directors than the common law. The introduction of this statutory duty reflects the modern commercial fact and contemporary attitude towards the management of companies as well as corporate governance best practices. ${ }^{47}$ Section 76 (3) (c) of the Companies Act relates to the director's duty to exercise care, skill and diligence and imposes a less subjective test; it tightens up the director's common law duty to exercise care and skill. ${ }^{48}$

Section 76(3) (c) states that:

Subject to subsections (4) and (5), a director of a company, when acting in that capacity, must exercise the powers and perform the functions of director- with degree of care, skill and diligence that may reasonably be expected of a person-(i) carrying out the same functions in relation to the company as those carried out by that director; and (ii) having the general knowledge, skill and experience of that director.

The Act has partially codified the director's duty to exercise care, skill and diligence, in so doing preserved both the objective and subjective elements. ${ }^{49}$ The duty sets a two legged test for the director, the first leg is contained in subsection (i) which is objective meaning that all directors should meet that threshold to avoid liability ${ }^{50}$ and subsection (ii) has a subjective test which requires the experience of that particular director. ${ }^{51}$ The consequence of the subjective element is that if a director is found to have greater knowledge and skill than could reasonably be expected of a person carrying out his or her functions in relation to the company, he or she will be held liable to a higher standard. ${ }^{52}$ The court will have to determine the degree of care, skill and diligence that may be expected of a director "carrying the same functions in relation to the company as those carried out by the director and secondly the court has to go further and make a value judgment as to the degree of care, skill and experience that can be expected from such a director". ${ }^{53}$ This duty of a director does not substitute the common law duty of the director to exercise care and skill. ${ }^{54}$ This means

\footnotetext{
${ }^{42}$ Section 60(1A) (a-b) of Banks Act 94 of 1990. For more details about the directors' duty to avoid conflict of interest, see JC Kanamugire "The Impact of the Companies Act 71 of 2008 on the Traditional Director's Duty to Avoid Conflict of Interest" (2014) vol. 5 No 9 MJSS 75, 76- 82.

${ }^{43}$ Section 60(1) (c-d) of Banks Act 94 of 1990. Section 40(c) and (d) of the Banks Amendment Act 19 of 2003, led the way towards legislating a more rigorous and less subjective duty of care and skill for directors.

${ }^{44}$ The King Report II chapter 4 at 55 in paragraph 2.3.

${ }^{45} \mathrm{lbid}$.

${ }^{46}$ Companies Act 71 of 2008 which come into effect on 1 May 2011.

${ }^{47} \mathrm{FHI}$ Cassim et al. Contemporary Company Law.2ed (2012) 558.

${ }^{48} / \mathrm{bid}$.

49JS McLennan. "Duties of Care and Skill of Company Directors and their Liability for Negligence" (1996) 8 SA Merc LJ 101.

50 See Dorchester Finance Co Ltd v Stebbing1989 BCLC 498 (Ch) where directors who were qualified accountants were held to be negligent for signing blank cheques because as professionals they were held to a higher standard of care expected of accountants.

${ }^{51}$ See Daniels (formerly practicing as Deloitte Haskins \& Sells) v Anderson(1996) 16 ASCR 607 NSW where the court distinguished skill from care. The court held that skill refers to the knowledge and experience that a director brings to his office as well as the technical competence of that particular director, while care is objectively assessed skill varies from person to person (subjectively assessed).

${ }^{52}$ L Conradie. "More indulgent approach to the directors' duties" (2011) Without Prejudice at page 14, she suggests that the imposition of the director's duty of care and skill is analogous to that of which professionals are bound.

${ }^{3} \mathrm{FHI}$, Cassim. et al....Contemporary Company Law. 2ed. (2012) 560

$54 \mathrm{lbid}$.
} 
therefore that a director can be held liable in terms of the common law principles of delict for any loss, damages or costs incurred by the company which resulted from the director's breach of his or her statutory duty of care and skill. ${ }^{5}$

The standard of care, skill and diligence is now partly objective ${ }^{56}$ and partly subjective. It is objective to the extent that the director must exercise the degree of care, skill and diligence that may reasonably be expected of a person carrying out the same functions as the director ${ }^{57} \mathrm{~A}$ director who accepts the position of director without the necessary knowledge, skill and experience does so at his or her own risk. ${ }^{58}$ The director who cannot demonstrate the degree of skill, care and diligence has an option to resign to avoid being held delictually liable for his or her conduct in the company's affairs. The test is also partly subjective to the extent that the knowledge, skill and experience of the particular director are also taken into account. ${ }^{59}$ The more skilled, knowledgeable and experienced the director is, the higher the level of skill that he or she must exercise. ${ }^{60}$ The level of care, skill and diligence that he or she must exercise must at least be what may reasonably be expected of a person carrying out some functions as those carried out by the director. ${ }^{61}$

The Companies Act62 shows the extent to which South African law has developed and is deviating from wellestablished common law principles. ${ }^{63}$ The common law has not been completely discarded by the Act ${ }^{64}$. In terms of section 77(2)(b), a director will be liable in accordance with the principles of the common law relating to delict for any loss, damage or costs sustained by the company by virtue of the director having breached his or her duty of care, skill and diligence. ${ }^{65}$

According to section 218 (2), ${ }^{66}$ any person who contravenes any provision of the Act is liable to any other person as a result of the contravention. This means that even a creditor can sue a director for failure of exercising care, skill and diligence in terms of this provision. ${ }^{67}$ Section 214 of the Companies Act states that a person will be guilty of an offence if he or she commits fraud against the company, the creditors or employees of the company. Over and above the civil and criminal liabilities which the director can incur if he or she breaches his or her duty of care, skill and diligence, he or she can also be declared delinquent in terms of section 162.68 In terms section 162 of the Act, the company or shareholders and certain other parties can apply to court for an order declaring a person to be delinquent or under probation if a director acts in any manner that amounts to negligence, wilful misconduct or breach of trust in executing his or her duties. ${ }^{69}$ Any declaration of delinquency will subsist for the lifetime of the person declared delinquent. ${ }^{70}$ This raises the bar in respect of the expected level of director's duties to companies in South Africa ${ }^{71}$ and it is not a surprise that the legislature decided to include the Business Judgment Rule to counteract the onerous provision in the Companies Act.

\section{The Business Judgment Rule (A New Defence for Directors)}

The Business Judgment Rule has been introduced in the Companies Act to try and soften the duty of care, skill and diligence which was codified by the new Companies Act. ${ }^{72}$ The rule was developed in the United States of America alongside the duty of care ${ }^{73}$ and it entails that courts should exercise restraint in holding directors accountable for business decisions which produce poor results. ${ }^{74}$ Provided that the director made a decision in good faith, with care and on an informed basis, the wisdom of business decisions are not within the scope of judicial review. ${ }^{75}$ The need for a rule of this kind in our law was echoed back in $1994^{76}$ where it was suggested that the 1973 Companies Act should be

\footnotetext{
${ }^{55}$ Companies Act 71 of 2008; section 77(b) (i) see also N. Bouwnman. "An Appraisal of the Modification of the Director's Duty of Care and Skill" (2009) 21 SA Merc LJ 516.

${ }^{56} \mathrm{FHI}$ Cassim. et al. Contemporary Company Law. 2ed. (2012) 560. It suggested that a number of factors will be taken into account ie the nature of the company, the nature of the business in question, the position of the director and the nature of responsibilities he undertakes.

${ }^{57}$ F Cassim. The Practitioner's guide to the Companies Act 71 of 2008 (2011) 91.

${ }_{58}$ M Bekink. "An Historical Overview of the Director's Duty of Care and Skill: From the Nineteenth Century to the Companies Bill of 2007" (2008) SA Merc LJ 111.

${ }^{59} \mathrm{~F}$, Cassim. The Practitioner's guide to the Companies Act 71 of 2008 (2011) 91.

$60 \mathrm{lbid}$.

$61 \mathrm{lbid}$.

62 Companies Act 71 of 2008

${ }^{63}$ See Daniels v Anderson16 ACSR 607 (CA) (NSW) at 661, the court held that the law of negligence has developed considerably in the last seventy years since the decision in Re City Equitable Insurance Co.

${ }^{64} \mathrm{D}$ Luckett, R Kramer "Read this before becoming a company director" (2011) September: Without Prejudice 19.

${ }^{65}$ Companies Act 71 of 2008, s 77(2) (b).

${ }^{66}$ Companies Act 71 of 2008, s 218(2).

${ }^{67}$ D Luckett, \&R Kramer "Read this before becoming a company director" (2011) September: Without Prejudice 19.

${ }^{68}$ E Levenstein. "Do you really want to be a company director" (2011) September: Without Prejudice 21.

${ }^{69}$ Companies Act 71 of 2008, s 162.

70/bid.

${ }^{71} E$ Levenstein "Do you really want to be a company director?" (2011) September: Without Prejudice 21.

72FHI Cassim.et al Contemporary Company Law.2ed. (2012) 563.

${ }_{73}$ S Kennedy-Good "The Business Judgment Rule (Part 1)" (2006) Obiter 62, 64.

${ }^{74} \mathrm{Ibid} 63$.

${ }^{75}$ Levin v Felt and Tweeds 1951 (2) SA 401 (A) 414. The court stated that "it is no part of the business of a court of justice to determine the wisdom of a course adopted by a company in the management of its own affairs."

${ }^{76}$ The Institute of Directors in South Africa (1994) November 9 paragraph 3.2-3.5
} 
amended to change the directors' duty of care and skill in order to encourage entrepreneurship ${ }^{77}$ and entice persons of skill to accept appointments in enterprises and the promotion of higher standards of corporate governance. ${ }^{78}$

The elements of the Business Judgment Rule in the American context are as follows: "a business decision; disinterestedness; due care; good faith; and no abuse of discretion or waste of corporation assets." 79 The purpose of the rule includes among other things encouraging risk taking; persuading competent persons to undertake the office of the director, prevention of judicial second-guessing; avoiding shareholder management in the corporation; and permitting effective market mechanisms to manage director behaviour. ${ }^{80}$

According to section 76(4) (a) ${ }^{81}$ a director is deemed or presumed to have exercised his or her powers with reasonable care, skill and diligence as contemplated by section 76(3) (b) and (c) if:

(i) the director has taken reasonably diligent steps to become informed about the matter;

(ii) either-

(a) the director had no material personal financial interest in the subject matter of the decision, and had no reasonable basis to know that any related person had a personal financial interest in the matter; or

(b) the director complied with the requirements of section 75 with respect to any interest contemplated in subparagraph (aa); and the director made a decision, or supported the decision of a committee or the board, with regard to that matter, and the director had a rational basis for believing, and did believe, that the decision was in the best interests of the company.

In exercising his or her duties, a director is allowed to rely on the company employees' information, opinions, reports or statements they provide. ${ }^{82}$ In addition the director can rely on legal counsel, accountants, or professional persons retained by the company, if the director reasonably believes that the matter falls within the particular person's professional or expert competence. ${ }^{83}$

Since the Business Judgment rule is borrowed from the United States of America, it is likely that the South African courts will look to court judgments from other countries in interpreting the rule. It is a pre-requisite for the rule to be applicable that the decision taken by the directors be rational as an irrational decision is indicative of bad faith..$^{84}$ In the case of Shuttleworth $v$ Cox Brothers \& Co (Maidenland) $L t d,{ }^{85}$ the court was of the view that the absence of rationality in deciding that a certain course of action will benefit the company can be an indication of lack of good faith.

A proper illustration of where the application of the Business Judgment Rule was considered is the case of Smith $v$ Van Gorkum. ${ }^{86}$ In this case, a class action was brought by the shareholders of Trans Union Corporation (a company) originally seeking the rescission of cash out merger of Trans Union. The company was alternatively seeking damages from the directors for their negligence in agreeing to sell the company's shares without giving due consideration to the price. In the court of first instance, judgment was given in favour of the defendant directors. The basis for the finding was that: the directors had acted in an informed manner so as to be entitled to protection of the Business Judgment Rule in approving the cash-out merger; and the shareholders' vote approving the merger should not be set aside because the stakeholders had been fairly informed by the Board of Directors before voting in favour of it.

On appeal the court reversed the decision of the court a quo as erroneous and held that the directors could not successfully invoke the Business Judgment Rule to escape liability. The court advanced the following reasons for its decision:

- the directors did not adequately inform themselves as to Van Gorkom's role in forcing the sale of the company and in establishing the par share purchase price; 87

- Van Gorkom, the director, had made a short presentation of approximately twenty minutes to the board;88

- Such a decision to sell the company needs more time to consider before making a decision; 89

- the directors were uninformed as to the intrinsic value of the company; ${ }^{90}$ and

\footnotetext{
${ }^{77}$ See Daniels (formerly practicing as Deloitte Haskins and Sells) v Anderson (1995) 16ACSR 607 (NSW), where the court held that "...the duty of a director may be to display entrepreneurial flair and accept commercial risks on behalf of the company."

${ }_{78}$ See also D Botha and R Jooste "A Critique of the Recommendations in the King Report Regarding a Director's Duty of Care and Skill" (1997) SALJ 65, 76.

${ }^{79} \mathrm{lbid}$ at 73.

${ }^{80}$ DP Lee "The Business Judgment Rule: Should it Protect Non-Profit Directors" (2003) 103 Columbia Law Review 925, 945-960.

${ }^{81}$ Companies Act 71 of 2008; s 76(4,)(a).

82P Delport "The New Companies Act Manual" (2009) 60

${ }^{83} \mathrm{Ibid}$.

${ }^{84} \mathrm{FHI}$ Cassim et al Contemporary Company Law.2ed. (2012) 564

${ }^{85}$ Shuttleworth v Cox Brothers \& Co (Maidenland) Ltd (1927) 2 KB 9 (CA) 23.

${ }^{86}$ Smith $v$ Van Gorkom 488 A.2d 858 (Del. 1985).

${ }^{87}$ Ibid.

${ }^{88} \mathrm{lbid}$.

$89 / \mathrm{bid}$.

golbid.
} 
- with the given circumstances, at the very least, the directors were grossly negligent in approving the sale of the company upon two hours consideration, without prior notice, and the exigency of a crisis or emergency.

It is important to note that there was no allegation of fraud, bad faith or self-dealing and it is therefore a classic example of balancing the director's duty of care, skill and diligence and business judgment of directors. ${ }^{91}$ So long as directors act in good faith, rationally and avoid conflict of interest the Business Judgment Rule allows them to avoid the rigorous duty to exercise care and skill.

The effect of the United States styled Business Judgment Rule is that it will neutralise the objective standard imposed by the partially codified duty of directors to exercise care, skill and diligence.

\section{Conclusion}

The new Companies Act has brought with it new changes like the American styled Business Judgment Rule and the partial codification of directors' duties of skill, care and diligence. The partial codification of the directors' duties has far reaching consequences ${ }^{92}$ to be considered by aspiring directors. The Act imposes liability on directors in the performance of their duty to exercise care and skill which has been partially codified to make sure that South African law is in line with other developed countries. The Business Judgment Rule therefore serves as a tool which alleviates the burden imposed by the new Act. The rule being an imported concept, foreign judicial decisions will be of guidance when judges are interpreting it. However, it should be noted that American courts have different rules of interpretation and the rule is not codified in the United States of America.

\section{References}

\section{Books}

Blackman M, et al Commentary on the Companies Act (online) ISSN 19914628

Cilliers, HS.et al. Corporate Law $2^{\text {nd }}$ ed. Durban: Butterworths, 1992

Cassim, FHI. et al. Contemporary Company Law $2^{\text {nd }}$ ed. Cape Town: Juta, 2012

Cassim, F. The Practitioner's Guide to the Companies Act 71 of 2008 Cape Town: Juta, 2011

Davies, PL.et al. Gower and Davies' Principles of Modern Company Law $8^{\text {th }}$ ed. London: Sweet and Maxwell, 2008

Delport, P. The new Companies Act Manual. Durban: Lexis Nexis, 2009

Gibson, JTR et al. South African Mercantile \& Company Law. $8^{\text {th }}$ ed. Cape Town: Juta, 2008

Jooste, R. The Comparative Guide to the Old and New Companies Act Cape Town: Juta, 2011

Loubser, A. Casebook on the law of partnership, Company Law, and Insolvency Law $13^{\text {th }}$ ed. Cape Town: Juta, 2008

Pretorius, JT et al. Hahlo's South African Company law through the cases $6^{\text {th }}$ ed. Cape Town: Juta, 1999

Pretorius, JT. Companies Act 61 of 1973, Close Corporations Act 69 of 1984 \& regulations.11 $11^{\text {th }}$ ed. Cape Town: Juta, 2008

Schoeman, T. Guide to the Companies Act and Regulations. Cape Town: Juta, 2000

Sealy, LS. Cases and Materials in Company law7th ed. Durban: Butterworths, 2001

Sharrock, RD. Business Transaction Law $8^{\text {th }}$ ed. Cape Town: Juta, 2011

Williams, RC. Concise Corporate and Partnership Law, $2^{\text {nd }}$ ed. Durban: Butterworths, 1997

Wixley, T \& Everingham, G. Corporate Governance Cape Town: Siber Ink, 2002

\section{Journal articles}

Actions: Viva Zapata?" (1981) 37 The Business Lawyer 27

Bekink, M. "An Historical Overview of the Director's Duty of Care and Skill: From the Nineteenth Century to the Companies Bill of 2007" (2008) 20 SA Merc LJ 95-116

Bekink, M. 'Indemnification and Aspects of Directors' and Officers' Liability Insurance in terms of Section 78 of the Companies Act 71 of 2008" (2011) 23 SA Merc LJ 88-105

Block DJ \& Prussin HA "The Business Judgment Rule and Shareholder Derivative Actions: Viva Zapata?" (1981) 37 The Business Lawyer 27 Botha D, \& Jooste R. "A Critique of the Recommendations in the King Report RegardingA Director's Duty of Care and Skill" (1997) 114 SALJ 65-76

Botha, MM. "The Role and Duties of Directors in the Promotion of Corporate Governance: A South African Perspective" 2009 Obiter $702-715$

Bouwman, N. "A new defence for directors" (Company Law) (2011) May Without Prejudice 12-13

Bouwman, N. "An Appraisal of the Modification of the Director's Duty of Care and Skill" (2009) 21 SA Merc LJ 509-534

Cassim, FHI. "Fraudulent or Reckless Trading and s 424 of the Companies Act of 1973" (1981) 98 SALJ 162-172

Conradie, L. "More indulgent approach to directors' duties" (2008) Volume 8 Issue 9 October Without Prejudice14-15

Du Plessis, J. "A Comparative analysis of the directors' duty of care, skill and diligence in South Africa and in Australia" (2010) Acta

${ }^{91} \mathrm{FHI}$ Cassim.et al.Contemporary Company Law. 2ed. (2012) 566.

92 The new Companies Act has introduced an objective standard to the directors' duty to exercise care, skill and diligence. 
Juridica 263-271

Finch, V. "Company Directors: Who Cares about Skill and Care" (1992) 55 Modern Law Review 179 -214

Hansen, C. "The All Corporate Governance Project: Of the Duty of Due Care and the Business Judgment Rule" (1986) 41 Business Law 1257

Havenga, M. "Director's Co-Liability for Delicts" (2006) 18 SA Merc LJ 229-237

Havenga, M. "The Business Judgment Rule - Should We Follow the Australian Example?" (2000) 12 SA Merc LJ 25-37

Jones, E. "Directors' Duties: Negligence and the Business Judgment Rule" (2007) 19 SA Merc LJ 326-336

Kanamugire, JC. "The Impact of the Companies Act 71 of 2008 on the Traditional Director's Duty to Avoid Conflict of Interest" (2014) vol. 5 No 9 MJSS $75-88$

Kennedy- Good S \& Coetzee L "The Business Judgment Rule (Part 2)" (2006) Obiter 277-292

Kennedy-Good, S \& Coetzee, L. "The Business Judgment Rule (Part 1)" (2006) Obiter 62-74

Lee, DP. "The Business Judgment Rule: Should it Protect Nonprofit Directors?" (2003) 103 Columbia Law Review 945-960

Levenstein, E. "Do you really want to be a company director?" (2011)September Without Prejudice20-21

Levenstein, E. "The personal liability of directors" (2011) June Without Prejudice21-23

Luckett, D \& Kramer K. "Read this before becoming a company director" (2011) September Without Prejudice 18-20

Mckenzie, AL. "A Company Directors' Obligations of Care and Skill" (1982) Journal of Business Law 460

McLennan, JS. "Duties of Care and Skill of Company Directors and Their Liability for Negligence" (1996) 8 SA Merc LJ 94-102

\section{Statutes}

\section{South Africa}

Auditing Profession Act 26 of 2005

Banks Act 94 of 1990

Banks Amendment Act 19 of 2003

Close Corporations Act 69 of 1984

Companies Act 71 of 2008

Companies Act 61 of 1973

Promotion of Administrative Justice Act 3 of 2000

Australia

Corporations Act 50 of 2001

United States of America

US Model Business Corporation Act 1984 (as revised 2002)

Canada

Canada Business Corporation Act, 1985

New Zealand

New Zealand Companies Act of 1993

United Kingdom

English Companies Act of 2006

\section{Cases}

\section{South Africa}

Cooper \& others NNO v SA Mutual Life Assurance Society \& others 2001 (1) SA 967 (SCA)

Dorklerk Investments Pty Ltd v Bhyat 1980 (1) SA 443 (W)

Du Plessis NO v Phelps 1995 (4) SA 165 (C)

Ex Parte Lebowa Development Corporation Ltd 1989 (3) SA 71 (T)

Fisheries Development Corporation of SA Ltd v Jorgensen; Fisheries Development Corporation of SA Ltd v AWJ Investments Pty Ltd 1980 (4) SA $156(\mathrm{~W})$

Fourie NO v Newton (2010) JOL 26517 (SCA)

Gordon NO and Rennie NO v Standard Merchant Bank Ltd \& others (1984) 2 SA 519 (C)

Heneway Freight Services (Pty) Ltd v Grogor 2007 (2) SA 561 (SCA) 
Howard v Herrigel 1991 (2) SA 660 (A)

McCarthy Ltd v Absa Bank Ltd 2010 (2) SA 321 (SCA)

Niagara Ltd v Langerman 1913 WLD 188

Ozinsky NO v Lloyd (1992) 3 SA 396 (C)

Page v First National Bank and Another 2009 (4) SA 484 (E)

Philotex (Pty) Ltd v Snyman; Braitex (Pty) Ltd v Snyman 1998 (2) SA 138 (SCA)

S v Goertz 1980 (1) SA 269 (C)

S v Harper \& another 1981 (2) SA 638 (D)

Australia

Australian Securities Commission v Gallagher (1993) 11 ACLCSR 286 (SC, WA)

Byrne v Baker (1964) VR 443 SC, (Vic)

Commonwealth Bank of Australia v Friedrich (1991) 9 ACLCL 946

Daniels (formerly practicing as Deloitte Haskins \& Sells) v Anderson (1995) 16 ACSR 607 (NSW)

Darvall v North Sydney Brick \& Tile Co Ltd (1989) 15 ACLR 230 (CA (NSW))

Harlowe's Nominee's (Pty) Ltd v Woodside (Lakes Entrance) Oil Co NL (1968) 121 CLR 483

Statewide Tobacco Services Ltd v Morley (1990)8 ACLC 827

Vrisakis v Australian Securities Commission (1993) 11 ACLC 763 SR 162 (SC, WA)

\section{United States of America}

Francis v United Jersey Bank 432 A 2d 814

In re Oracle Corp Derivative Litig 824 A 2nd 917 (Del Ch 2003)

In re Walt Disney Co Derivative Litigation (825A $2^{\text {nd }} 275$ Del Ch. 2003)

Krasner v Moffat (826 A 2nd 277 (Del 2003)

Panter v Marshall Field \& Co (646 F 2d 271 ( $7^{\text {th }}$ Cir 1981)

Schlensky v Wrigley 237 NE 2d 776(1968 App Ct of III)

Smith v Van Gorkum 488 A 2d 858 (Del Supr 1985)

Telxon Corp v Meyerson 802 A 2nd 257 (Del 2002)

United Kingdom

Boardman v Phipps 19663 ALL ER 721 (HL)

Dorchester Finance Co Ltd v Stebbing (1989) BCLC 498 (Ch)

Dovey v Cory 1901 AC 477 (HL)

Howard Smith v Ampol Petroleum Ltd 19741 ALL ER 1126 (PC)

Huckerby $v$ Elliot 19701 All ER 189 (QB)

Lagunas Nitrate Co v Lagunas Syndicate (1899) 2 Ch 392

Multinational Gas \& Petrochemical Co Ltd v Multinational Gas \& Petrochemical Services Ltd 19832 All ER 563 (CA)

Re Barings plc (No 5) 19991 BCLC 433 (ChD)

Re Brazilian Rubber Plantations \& Estates Ltd (1911) Ch 425 (CA)

Re City Equitable Fire Insurance Co Ltd (1925) Ch 407

Re City Equitable Life Assurance Society v Human (2002) 1 AC 408.Re Smith \& Fawcett Ltd (1942) Ch 304

Re D'Jan of London Ltd (1994) 1 BCLC 561 (Ch)

Re National Bank of Wales Ltd (1899) 2 Ch 629 (CA)

Sheffield and South Yorkshire Permanent Building Society v Aizlewood (1889) 44 ChD 412

Shuttleworth $v$ Cox Brothers \& Co (Maidenhead) Ltd 19272 KB 9 (CA)

Sub Nom Secretary of State for Trade and Industry v Baker and others (No 5) (1999) 1 BCLC 433 (Ch D)

Turquand v Marshall (1869) LR 4 Ch App 376

\section{Reports}

King Report on Corporate Governance (The Institute of Directors Southern Africa 1994); the Institute of Directors in South Africa, 2002 March

\section{Internet sources}

"Directors Duties in a Vastly Different Corporate Landscape" (2009)

http://www.bowman.co.za/News-Blog/Blog/Directors-duties-in-a-vastly-different-corporate-landscape (accessed on 17 May 2014) 